Article

\title{
How Can Teachers Be Encouraged to Commit to Sustainability? Evaluation of a Teacher-Training Experience in Spain
}

\author{
Mercedes Varela-Losada ${ }^{1}$, Azucena Arias-Correa ${ }^{1}$, Uxío Pérez-Rodríguez ${ }^{1}[\mathbb{D}$ and \\ Pedro Vega-Marcote ${ }^{2, * \mathbb{D}}$ \\ 1 Faculty of Education and Sport Sciences, University of Vigo, A Xunqueira, 36005 Pontevedra, Spain \\ 2 Faculty of Education Sciences, University of A Coruña, Campus Elviña, 15071 A Coruña, Spain \\ * Correspondence: pedro.vega.marcote@udc.es; Tel.: +34-881-014633
}

Received: 5 July 2019; Accepted: 7 August 2019; Published: 9 August 2019

\begin{abstract}
The main objective of this study was to design and evaluate an experience for future teachers focused on the participatory search for sustainability through role play so that outcomes related to improving the way they see the world and their commitment to mitigate climate change could be analysed. The study was carried out with a socio-critical focus, using a qualitative approach. To this effect, semi-open interviews were conducted, and their results were codified and studied using content analysis. The outcomes show that this type of educational experience can contribute to improving commitment to climate change and new, more sustainable ways of understanding the world—starting with improving the training of free-thinking, discerning people who are able to use information and collaborate in solving socio-environmental problems. Proposals based on participatory and experiential learning, fostering ethical considerations and the training of people who are more critical and discerning, should be the basis of new models of Environmental Education for Sustainability that seek to educate a society capable of addressing present and future socio-environmental challenges.
\end{abstract}

Keywords: environmental education; sustainability; teacher training; climate change; role play

\section{Introduction}

At the beginning of the 21st century, we find ourselves in the midst of a great environmental and humanitarian crisis. Climate change (CC) is a paradigmatic example of the problems we face nowadays. The search for its mitigation and adaptation can put us on the path to sustainability.

$\mathrm{CC}$ is one of the main socio-environmental problems, as noted by many international agencies [1,2] that warn of the consequences our greenhouse gas emissions will have on the viability of the planet. Already in 2012, the World Bank [3], a body not prone to radical policies, exposed the risks of this change: "As global warming approaches and surpasses $2{ }^{\circ} \mathrm{C}$, there is a risk of provoking non-linear inflection points, with consequences such as the melting of Western Antarctica, an increase in the rate of rising sea levels, the gradual demise of the Amazonian rainforests, [etc.]". Likewise, the latest report by the IPCC (2014) [4] on risks and potential impacts warns of different scenarios based on how we evolve and adapt to CC, where the most optimistic situation-with the implementation of global mitigation measures-already has significant consequences in people's lives and that of the planet, such as a decrease in freshwater resources, risks for coastal systems, and impacts on food production and our health.

In addition, it must be taken into account that CC is part of a global environmental change which is significantly influencing the functioning of the Earth's system in many areas and is being driven by the exponential growth of the human population and of human activities [5]. Together with the 
different processes involved in this global environmental change, CC represents a problem of enormous environmental, social, economic, political, and heritage dimensions and represents a great challenge for humanity [6]—one which should make us think about the need to change the current, unsustainable, and ethically unfair development model $[7,8]$.

To achieve a future scenario of low emissions [4], a change in economic and business policies is necessary. This is progressing slowly with treaties such as the Paris Agreement, within the framework of the United Nations Framework Convention on Climate Change. Of course, it is also vital that people change their lifestyles, moving towards more sustainable and conscious habits.

In this transition, education plays a key role, as emphasised by the UN Sustainable Development Goals [9]. However, authorities in the field, such as The Worldwatch Institute [10], note that education is often designed to "train people to be employees and consumers," exacerbating our current problems and promoting consumerism as the dominant cultural context in which most students now grow up.

Therefore, the university, being responsible for the basic training of teachers (and many other professionals), should get involved and be active in the search for new educational models within the framework of sustainability [11,12]. Although there is concern for the environment among teacher trainers, many of these initiatives base their curriculum focus on increasing teachers' awareness of environmental issues and environmental content knowledge, but few address key issues associated with the need to change worldviews [13]. Thus, study has shown that the basic training of teachers has important shortcomings regarding Environmental Education, sustainability, and climate change [14-17].

Likewise, there is a need for more experiences that focus on understanding learning processes and the development of the capacities that people (and communities) need to help solve socio-environmental problems, paying special attention to their cognitive and emotional responses and the influence of their cosmovisions and complex belief systems [18]. In this framework, it is essential to redefine the new educational scenarios, along with the roles of teachers and of all other people and organisations within the educational community [19], leaving behind traditional approaches focused on instilling habits. The main role of schools should be to influence the development of the capacities of students (and the educational community), using ways of teaching where students acquire the courage, commitment, and desire to get involved as active and responsible participants [20].

In this context, a didactic proposal for basic teacher training focused on the study of CC and the participatory search for sustainability through role play was designed and carried out. The main objective of the study was to evaluate, after this experience, improvement in the future teachers' worldviews and their commitment to mitigating CC. This research was part of a larger study that also examined the commitment of the participants to the integration in schools of environmental education aimed at achieving sustainability in their future professional careers. The results of the aforementioned study have been published elsewhere [21].

\section{The Didactic Proposal Focused on Participatory Search for Sustainability}

In the current scenario-tackling the problem of fossil fuel depletion and the consequences of CC-students should be given support so they can become literate citizens capable of making informed decisions regarding energy and consumption [22]. Thus, schools must prepare people to understand socio-environmental problems such as these so that they can analyse them and look for new solutions and more responsible and sustainable lifestyles.

For this reason, Environmental Education for Sustainability must be based on finding new ways of looking at the world from a holistic and critical approach towards the prevailing socioeconomic models and current lifestyles [23]. It is, therefore, a complex process that entails acquiring conceptual knowledge but also developing competences, values, attitudes, aptitudes, and ways of behaving regarding social interaction, collaboration, and dialogue $[24,25]$. For this reason, education that just provides information about the environment is not enough; emotional, attitudinal, and action components must also be considered, making it possible to expose the adopted models of action, values, and unconscious attitudes.

From this perspective, the design of this educational proposal was based on the suggestions of authorities in the field [26]: 
- It uses methodologies based on the study of sustainability and solving relevant/real/close-to-home problems, with approaches based on reflecting on the complexity of environmental issues with a global perspective on the causes, consequences, and possibilities of action $[19,27,28]$.

- It promotes information literacy and the development of critical thinking, facilitating the formulation of critical questions, reflection, debate, and analysis of the world from plural and gender perspectives. It pays special attention to the role of people in the system and the influence of sociocultural and economic factors on their lifestyles [19,28-30].

- It makes exposing the adopted models of action, values, and unconscious attitudes possible, seeking to encourage independent decision-making-showing responsibility towards the environment and people-and the promotion of sustainable lifestyles [27,31].

- It promotes building self-knowledge in a social environment and the participation of students in the process, seeking not only to motivate and teach but also to develop a democratic culture based on dialogue and participation [28,32].

- It seeks to integrate the community and encourage the collaboration of people from the area, fostering the creation of learning networks that encourage the transfer of learning $[28,33]$.

Following these guidelines, a role play activity [34] based on a CC-related socio-scientific controversy was specially designed for teachers in training and carried out via integration into a study programme on didactics of Environmental Education for Sustainability [26]. Its phases are shown in Table 1.

Table 1. Phases of the role play activity on the socio-scientific controversy relating to climate change (CC) and current lifestyles.

\begin{tabular}{cl}
\hline Phase & \multicolumn{1}{c}{ Actions } \\
\hline & I.1. Reading news related to CC (especially nearby causes and consequences), which the students \\
must compare and interrelate, promoting the development of prior ideas and doubts that will be \\
the driving force of the study. \\
I.2. Initiation of the role play activity with another news item on the installation of a new \\
alternative energy plant in the area, which raises the idea of the simulation of decision-making in \\
this case and taking on the different roles identified (local government, clean energy associations, \\
oil company alliances, land associations, the nuclear safety council, etc.). \\
I.3. Development of research questions and analysis of the situation \\
(science-technology-society-environment interrelationships) addressing issues such as the \\
following: causes and consequences of CC, uses of energy, possible ways of approaching the \\
problem (of a techno-scientific/social transformer nature), advantages and disadvantages, etc. \\
II.1. Search and critical treatment of information, consulting experts (local Non-Governmental \\
Organizations, environmental scientists, etc.) and watching documentaries. \\
II.2. Restructuring and collaborative synthesis of information, where each party involved prepares \\
their rationale based on the assigned role, encouraging the analysis of the information collected \\
and explaining the beliefs and values that are behind each position. \\
III.1. Preliminary reflection on certain fundamental issues of the case: Is exploiting alternative \\
energies a good solution? How is our behaviour related to the energy problem? How do political, \\
sociocultural, and economic factors influence our lifestyles? Are social transformation and the \\
consumerist model necessary? \\
III.2. Debate and consensus decision-making, based on difficulties and action priorities, which \\
address not only the question raised but also individual and community responsibility for the \\
problem. What can we do in our lives? How can we involve our families? \\
III.3. Shared evaluation and reflection on the learning process.
\end{tabular}

These controversies are an ideal context for students to get involved in complex issues, develop new knowledge, and improve their scientific and environmental literacy [35]. They are based on the idea that one of the main objectives of science education is to prepare people to take part in decisions that affect their daily lives, such as their health, the appropriate use of new technologies, or the use of energy [36]. 
A proposal like this one, in addition, encourages democratic participation [37] and addresses the ethical dimensions of socio-environmental problems, as "ethics and value judgments are behind almost every decision that is connected to $\mathrm{CC}$, including decisions taken by individuals, public and private organisations, governments and groups of governments" [38], and it is one of the main potentialities that must be addressed from university to combat CC, beyond technological and economic aspects [39]. When decision-making is framed around socio-scientific issues, students must face difficulties related to cognitive operations and moral conflicts, such as accepting evidence that contradicts their own thoughts [40], as personal values and worldviews have an important role in these processes-as noted by various authors [41,42].

Other authors, nevertheless, also note difficulties when implementing this type of methodology. Thus, students are not always able to develop autonomous learning [43] or may show perspectives that are overly limited when representing complex problems [37] (aspects that were taken into account in designing this experience).

\section{Materials and Methods}

This educational intervention was implemented throughout the second quarter of 2017 with a group of 25 trainee teachers, divided into six cooperative teams formed on the basis of common interests, taking the optional subject of "Environmental Education for Development" within the Primary Education Degree of the Faculty of Physical Education and Sport Sciences in Pontevedra. Of this group, $78 \%$ were women and 22\% were men. Regarding age, $66 \%$ were aged between 18 and 22, $24 \%$ between 22 and 30 , and $10 \%$ were over 30 . These students had not received any specific training on sustainability and CC during their time at university.

The study was conducted following a social-critical approach [44], based on a complex vision of reality. This type of approach, framed in an educational context, tries to empower teachers and students to think and to act in the interest of social and environmental justice, sustainability, and democracy [45]. In this case, the aim was to reflect and to improve the sustainable perspective of the future teachers' worldviews in relation to the production and use of energy. So, emphasis was placed on critical social thought, media literacy, and community problem-solving through a research activity [45].

In the study, a qualitative approach was used where the significance each person attributes to their experience and, as a result of these, how they define it, how they understand it, and how they explain it, was of interest [46]. To this effect, an intrinsic-type case study was carried out [46].

To add credibility to the study, data collection and analysis was carried out by two researchers with a thorough insight of the context and who have spent a long time in the environment under study. This facilitates a deep understanding of the study phenomenon and the transfer of details about the location and people, giving credibility to the narrative [47]. In order to obtain a rich, solid, and well-developed description, the triangulation of sources technique was used, comparing the accounts of participants in the experience with different points of view and the triangulation of analysts with feedback $[47,48]$. In addition, direct observation was carried out, and notes were taken of the entire process of implementing the educational initiative (especially in the role play activity).

Thus, two weeks after developing the educational experience, semi-open, face-to-face interviews were conducted with the future teachers, wherein relevant questions were asked regarding the experience undertaken and their worldviews, especially on the subject of generating and mitigating CC and of our development model (see Appendix A). The subthemes of the interview were selected a priori and their choice was based on a review of the literature (establishing a series of main questions that were complemented by secondary questions). This methodological approach can be adequate to delve more deeply into people's environmental convictions, experiences, and actions related to CC and other socio-environmental problems $[49,50]$. Six people of the class group were interviewed-two male students and four female students, who we will call Boris, Pablo, Estefania, Silvia, Maria, and Ines-whose selection was made according to the following criteria: representativeness of the group, gender, age, context (rural/urban), academic training, and their involvement in the classroom. 
The data were processed by two analysts using an interpretive methodology [51], applying codification and analysis of content. This technique is one of the most used for organising data obtained in qualitative studies and it enables inferences to be drawn, as well as the systematic identification of the specific characteristics of the messages [52].

\section{Results and Discussion}

\subsection{Speaking about Climate Change}

Following the experience carried out in the classroom, all the people interviewed said they were aware of the importance of the current effects of climate change in their present and future lives. They all talked about the effects they have noticed in their lives. Silvia said, "If you live in a big city you can see it. When I go to Madrid I notice the heat when I'm approaching, and you can clearly see a cloud over Madrid." Inés also pointed out that in recent years they have not had any water in their village house, and Estefanía commented that she has noticed how dry her skin feels. When we questioned them to see if they thought it was an over-exaggerated problem, the great majority of the group answered no. Maria pointed out that, "In fact nothing has been exaggerated, because nobody knows the consequences that it may have; that is, the real consequences it may have is the great unknown. Everything depends on us and I believe that it can't be emphasised enough, what happens is that ... people prefer not to believe it because you see it on a small scale." In fact, both Pablo and Silvia thought that it should be emphasised more to raise greater awareness of the problem; Silvia said, "It's better to show the most extreme data so that people can see the limits we may reach."

With reference to this, two of the people interviewed spoke of the influence that the people in their circles who deny this problem had had on them and how that had affected their views on the effects of CC before the educational experience. Estefania said, "One of the teachers who taught me in secondary school put the idea into my head that CC did not exist," and Ines recounted how a fellow student spoke to her of "that CC invention that my husband and I are convinced has been made up by paranoid conspiracy theorists." Thus, the data extracted show that there is still a great tendency for people to disagree on, and have conflicts about, the gravity of CC, which has also been shown by other studies carried out in different countries $[53,54]$, and that can affect students if they do not work in this area specifically.

In addition, after the experience, students not only talked about the seriousness of the consequences of CC but also seemed to be aware of the asymmetries and inequalities that occur where there are areas that are more affected than others, especially in underdeveloped regions [4,55]. Maria explained, "Obviously the fewer resources you have, the greater the impact will be."

With reference to generating CC, mainly regarding the production and use of energy, the group seemed to be aware of its problems. Thus, the decision taken at the end of the role play showed the whole class's commitment to a need for a change of model. During the interview, Estefania, Pablo, and Boris expressed their concerns about the squandering of energy and spoke of the "need for a transition towards clean energies." Estefania asked herself, "How we are going to promote a change if we are accustomed to our comfy lifestyles." Furthermore, Silvia spoke of "how we need energy for everyday living". In addition, Ines was worried, mainly, about "the inequality that exists in accessing energy depending on circumstances".

The interviewees' declarations seem to show a holistic view of energy-related issues. They talked about their natural, social, and economic dimensions, which are crucial dimensions for teaching and understanding socio-environmental problems in school. Likewise, the intervention seems to alleviate the lack of a specific treatment of these dimensions in their future classrooms, a problem reported by authors such as Herman, Feldman, and Vernaza (2017) [16], who linked this lack with a danger that students will not connect CC and its mitigation with their daily lives.

Similarly, all the people interviewed know the relationship between the use of certain means of transport and greenhouse gas emissions. When we questioned them on the use of cars, they seemed to 
be concerned about the consequences. However, in spite of this concern, four of them professed that they normally used cars. People living in rural areas spoke of how they depended on cars to get to the university campus and of the need to find new options. Another person interviewed (Silvia) spoke of "the convenience of using cars and of the sacrifice involved in not using one". In contrast, Boris and Pablo defended the use of more sustainable means of transport and claimed that walking and cycling were their usual means of transport, although when analysing this issue, it would be appropriate to take into account the gender differences noted in the literature [56].

As noted by authors such as Gardner and Stern (2002) [57], high-impact behaviours for CC (for example, driving) tend to be very important for people who are set in their ways, and these daily habits are often based mainly on contextual factors (for example, trip distance/difficulty of taking alternatives) and, therefore, are more difficult to change [57]. This raises the question of whether it is possible to achieve changes in people's lifestyles without institutional support to facilitate such advances.

\subsection{Speaking about Our Socioeconomic Model and Our Responsibility in Socio-Environmental Problems}

The development of the educational experience and the solution chosen in the role play activity showed that the class group opted for a solution based on social transformation which should be driven by all spheres of the society. This idea was also reflected in the data collected in the interviews.

After the experience, all the people interviewed agreed that responsibility in socio-environmental problems (like CC) is a responsibility shared among government, companies, and citizens. In particular, the role of the government seems fundamental to them (Boris, Estefania, Ines, Maria). However, they also indicated the importance of the actions of the people; Estefania defended, "The voice of the people doesn't clearly tell the government what it must do," while Pablo asserted, "We are all partly to blame. I believe that everything starts with us. If we consume, if we have things and want to have more and more, companies are going to take advantage of that ... and the governments are going to make policies that benefit companies".

In fact, when they were asked directly if they had it in their power to be able to solve socio-environmental problems individually, they all agreed that yes, they could. Four of them were conscious of the key importance of joint participatory operations in contributing towards solving these problems. Ines suggested that "We must do it together ... with a big social movement."

With regard to our development model, when we asked them if the best indicator of the prosperity of a country is its economic growth, the answers seemed to show critical stances regarding the model. The six people surveyed considered key questions concerning the phrase, and Ines indicated, "Only if prosperous means quality of life, education, health." Maria considered the conditions that economic growth imply: "What consequences are we going to have to suffer to reach that economic growth?" Pablo thought, "That is what they want us to create but the country ... I believe that a prosperous country ... it's a country in which everybody shows solidarity ... where economic growth must be equitable." Boris, in addition, indicated that the subject studied had helped to bring about a change in his perspective: "I don't think the same now. I believe that it is something that has to do with economic wealth but not with true prosperity." Although the answers by Ines and Estefania also showed the great importance that the economic factor has in their lives, for both, prosperity is bound to economic growth.

In spite of this critical stance regarding the socioeconomic model based on growth and consumption shown in its discourse, none of the people interviewed seemed to be truly committed to responsible consumption or showed characteristics of critical consumers [58].

Therefore, when we asked them if they wanted to know how the goods they consumed were produced, three preferred not to know; in fact, Maria asserted, "The truth is I prefer not to know, for that reason ... because it is easier to stick your head in the sand, so to speak, isn't it? Because it's the easy option," and Ines said, "I don't take anything into account".

The other three people usually read the information on labels, mainly for reasons related to their individual health. However, they also stated that the purchase decision really did not depend on 
that. Silvia told us that she was interested in knowing if "it's made in Morocco and with certain materials, but I'm going to buy it anyway," just as Estefania confessed, "If I like it I am going to buy it anyway," and Pablo said, "Just by knowing if it comes from China or Taiwan, you get an idea of how it's produced, how it's transported ... but we buy it anyway because really almost everything comes from there, so it's difficult." Maria stated, "Well, until we spoke in class about what happens with the cheapest products, I had never stopped to think about it clearly, and I believe that yes, it's something I will consider from now on ... When I see really, really cheap clothes, I say OMG, how much profit can they be making with these clothes if they can sell them for one euro? Yes, I do consider these aspects but then I end up buying them anyway." The same person also highlighted that "there are many social impositions... it's like stereotypes... we are affected by everything, by the media... influenced by everything." Pablo also said, "I see people so, so conditioned by advertising, by consumerism, that I think it is going to be very difficult to change their minds".

After the experience, the students interviewed seemed to understand that their consumer habits affect society and the environment, but they are not prepared to change their ways, showing again the "breach" that can exist between cognition and action, as noted by various authors [59,60]. Studies, such as that by Álvarez, Sureda, and Coma (2018) [17] carried out in a similar Spanish context, also point to the poor commitment to action in solving socio-environmental problems by future teachers who have a high level of environmental awareness.

\subsection{The Influence of Educational Intervention}

The follow-up of the process suggested that the experience had been carried out in a positive way and reflected the students' motivation and interest in taking part in all the tasks performed; after the experience, a change was noticed in their ability to critically analyse the information, reflection capacity, and participation in the socio-environmental debate.

Thus, the data collected seem to show that after the educational intervention, there was an increase in concern about CC and greater awareness among the students about how this socio-environmental problem is generated and its relation with sustainability. In fact, when they were asked if they had changed their ways of thinking after addressing this, they all said yes, to a greater or lesser extent. Silvia spoke about how she now knows much more and Ines professed, "I see the issue of climatic change in a worse light now ... its consequences on the planet, above all, after reading all those articles. It is affecting absolutely everything ... it's important to address it in the classroom someday".

Ines and Pablo thought that people nowadays were more critical; hence, Pablo said, "I am a little more critical about what is happening and I'm trying a little harder to pay attention to ... what I said before about not wasting so much or changing my lifestyle a little, so as not to contribute ... not to be an active part of the situation that makes climate change worse." Maria maintained that she is much more conscious: "Like before, as you said in the previous question that it was exaggerated, I did not think that the climatic change was exaggerated but that it was something good ... that it was a long way off, that it wouldn't affect me, but now yes, I believe this; that is, I'm scared thinking about it because I think so, that we would have to make things much more radical, but I don't know, it's very difficult".

As Maria's statements reflect, it's necessary to highlight that the results regarding changes in their lifestyles were moderate. Although, after the experience, they seemed to have a critical position with a socioeconomic model based on growth and consumption, their statements on changing their lifestyles expressed the difficulties and ignorance that they have and their concern about losing quality of life. In relation to this, their position on consuming seems especially worrying to us, since most of the people interviewed choose not to know how things are produced or prefer not to use this issue as a purchase criterion [55]. These data seem to show the difficulties that people have in changing their lifestyles and consumer habits after growing up in a cultural context dominated by consumerism [10]. Along these lines, Schindel (2015) [61] warned of the influence of the neoliberal context on citizenship and on the risk of promoting a diluted and individualistic form of environmental engagement similar to that found within this ideology. 
In any case, the data collected suggest that the experience encouraged a change in perspective, based on reflecting on the problems of CC and promoting critical thought, facilitating their commitment to mitigating it. This can be a first step towards thinking critically about our lifestyles, but future interventions must also mainly seek to encourage participatory action in the search for solutions to socio-environmental problems concerning consumption. It would be very interesting to improve the specific phase in this proposal that carries out a more in-depth study on the relationship between consumption, the use of the energy, and CC. While assessing this, it is also necessary to consider that it is a subject that only lasts a term and that the rest of the university community/social surroundings does not take part in it.

In short, the training proposal must continue progressing and reinforcing some fundamental elements. One improvement could be accomplishing new tasks to be implemented in the last phase of the cycle of learning on sustainability, where real actions related to the subject matter dealt with in the classroom are designed and implemented, enabling the students to improve their perceptions on the importance of thinking about participatory action. In addition, it seems fundamental to begin to work on responsible decision-making in relation to consumption and to involve the rest of the university community, promoting the "greening" of degrees like this [62].

\section{Conclusions}

The teaching staff are a key factor in the transition towards schools and communities committed to the environment and people. The proposal evaluated herein approaches their training based on the importance of living, innovating educational experiences that enable future teaching staff to reflect on CC and the lack of sustainability.

The results show that this type of practice based on experiential and participative learning, where ethical considerations are promoted, can contribute to improving this involvement, as well as training free-thinking, discerning people capable of using information in a critical manner to collaborate in socio-environmental problem-solving. Thus, the data collected seem to show a positive change in terms of their new ways of seeing and understanding the world, seeking solutions related to social transformation [8]. The results also suggest that this change can be reflected in the way problems such as CC can be addressed in their future classrooms, a way that is more participatory and holistic [27], adding value to social, political, and economic dimensions-very relevant aspects that are not usually addressed in schools [16].

However, the results regarding changes in their lifestyles are limited, which shows the difficulties of this objective, seemingly attainable only through the participation of the community and of the institutions involved, such as administrations and universities, in order to move towards sustainability [63]. Therefore, experience should reinforce this issue, as discussed in the previous section.

In relation to the design of the study, it is also important to note that the sample used is small and therefore does not enable results to be generalised, which would be necessary for long-term monitoring to assess the continuity of the lessons learnt. It is likewise necessary to consider its results while taking into account the limitations of qualitative methodology.

Therefore, it would be advisable to continue investigating proposals that can be the basis of new educational models seeking to educate a society that is able to take on present and future socio-environmental challenges and to address the quest for sustainability.

Author Contributions: Conceptualisation, M.V.-L. and P.V.-M.; methodology, M.V.-L. and A.A.-C.; implementation of the proposal, M.V.-L.; content analysis, M.V.-L. and A.A.-C.; writing-original draft preparation, M.V.-L.; writing-review and editing, M.V.-L., U.P.-R. and P.V.-M.; visualisation, U.P.-R.; supervision, M.V.-L. and P.V.-M.; funding acquisition, U.P.-R. and P.V.-M.

Funding: This research was funded by Ministry of Economy and Competitiveness (Spain), grant number EDU2015-6643-C2-2-P, and Ministry of Science, Innovation and Universities (Spain), grant number EDU2017-82915-R. The APC was funded by University of A Coruña (Spain). 
Conflicts of Interest: The authors declare no conflict of interest. The funders had no role in the design of the study; in the collection, analyses, or interpretation of data; in the writing of the manuscript; or in the decision to publish the results.

\section{Appendix A}

Table A1. Semi-open questions asked in the interview.

\begin{tabular}{|c|c|}
\hline Subthemes & Open Questions \\
\hline $\begin{array}{l}\text { Responsibility for } \\
\text { socio-environmental } \\
\text { problems }\end{array}$ & $\begin{array}{l}\text { With whom do you think the main responsibility in the generation of environmental } \\
\text { problems lies? In governments? In companies? } \\
\text { As individuals, do we have the power to solve environmental problems? } \\
\text { Do you think the changes/solutions should come from above? }\end{array}$ \\
\hline Economic model & $\begin{array}{l}\text { What do you think of this statement: The best indicator of a country's affluence is its } \\
\text { economic growth? } \\
\text { Do you think that the factor that most determines a person's well-being is their income? }\end{array}$ \\
\hline Consumption & $\begin{array}{l}\text { Do you consider yourself a big consumer or a frugal person? } \\
\text { When you make a purchase, do you want to know how the things you are buying have } \\
\text { been produced? Or would you rather not know? }\end{array}$ \\
\hline Climate change & $\begin{array}{l}\text { Do you know that there is a section of society that thinks CC does not exist? } \\
\text { Do you think the severity of climate change has been exaggerated? } \\
\text { Do you think CC has a very significant effect on your life? }\end{array}$ \\
\hline $\begin{array}{l}\text { Production and } \\
\text { energy expenditure }\end{array}$ & $\begin{array}{l}\text { What do you think about our responsibility towards climate change? } \\
\text { Do you think we should change our consumption habits regarding energy expenditure? }\end{array}$ \\
\hline Transport & $\begin{array}{l}\text { What do you think about using cars? Do you think it can lead to a huge increase in } \\
\text { climate-change-producing gases? }\end{array}$ \\
\hline $\begin{array}{l}\text { Influence of the } \\
\text { didactic intervention }\end{array}$ & $\begin{array}{l}\text { Do you think that after having studied the subject, you have changed your mind? } \\
\text { Or changed your lifestyle? }\end{array}$ \\
\hline
\end{tabular}

\section{References}

1. IPCC. Global Warming of $1.5^{\circ} \mathrm{C}$. Intergovernmental Panel of Climate Change. Available online: https: //www.ipcc.ch/sr15/ (accessed on 23 July 2019).

2. UE. Climate Change. European Commision. Available online: https://ec.europa.eu/clima/sites/clima/files/ docs/factsheet_climate_change_2015_en.pdf (accessed on 23 July 2019).

3. World Bank. Turn Down the Heat; The World Bank: Washington, DC, USA, 2012.

4. IPCC. Climate Change 2014: Impacts, Adaptation and Vulnerability. Intergovernmental Panel of Climate Change. Available online: http://www.ipcc.ch/report/ar5/wg2/ (accessed on 2 April 2019).

5. Steffen, W.; Sanderson, R.A.; Tyson, P.D.; Jäger, J.; Matson, P.A.; Moore, B., III; Oldfield, F.; Richardson, K.; Schellnhuber, H.J.; Turner, B.L.; et al. Global Change and the Earth System: A Planet under Pressure; Springer Science \& Business Media: Berlin, Germany, 2006; ISBN 978-3-540-26594-8.

6. Steffen, W.; Stafford, M. Planetary boundaries, equity and global sustainability: Why wealthy countries could benefit from more equity. Curr. Opin. Environ. Sustain. 2013, 5, 403-408. [CrossRef]

7. Rockström, J.; Planeta, N. Programa de Las Naciones Unidas Parael Medio Ambiente Medio Ambiente Para el Desarrollo, PNUMA. Available online: http://www.unep.org/ourplanet/2011/sept/sp/article5.asp (accessed on 2 April 2019).

8. Folch, R. La Quimera del Crecimiento: La Sostenibilidad; RBA: Madrid, Spain, 2011; ISBN 978-84-9006-019-3.

9. UN. Transforming Our World: The 2030 Agenda for Sustainable Development. Resolution 70/1 Adopted by the General Assembly of United Nations. Available online: http://www.un.org/en/ga/search/view_doc.asp? symbol=A/RES/70/1\&Lang=E (accessed on 2 April 2019).

10. Worldwatch Institute. State of the World, 2017: EarthEd; Rethinking Education on a Changing Planet; Worldwatch Institute: Washington, DC, USA, 2017; ISBN 978-1-61091-842-8.

11. Ull, M.Á.; Piñero, A.; Agut, M.P.M.; Minguet, P.A. Preconcepciones y actitudes del profesorado de Magisterio ante la incorporación en su docencia de competencias para la sostenibilidad. Ensen. Cienc. 2014, 32, 91-112. [CrossRef] 
12. Leal Filho, W. Climate Change Research at Universities: Addressing the Mitigation and Adaptation Challenges; Springer: Cham, Switzerland, 2017; ISBN 978-3-319-58214-6.

13. Gough, A. Teacher education for sustainable development: Past, present and future. In Teaching Education for Sustainable Development at University Level; Leal Filho, W., Pace, P., Eds.; Springer: Berlin, Germany, 2016; pp. 109-122. ISBN 978-3-319-32926-0.

14. Yavetz, B.; Goldman, D.; Pe'er, S. Environmental literacy of pre-service teachers in Israel: A comparison between students at the onset and end of their studies. Environ. Educ. Res. 2009, 15, 393-415. [CrossRef]

15. García-Esteban, F.E.; Murga-Menoyo, A. El profesorado de educación infantil ante el desarrollo sostenible. Necesidades formativas. Ensen. Teach. 2015, 33, 121-142. [CrossRef]

16. Herman, B.C.; Feldman, A.; Vernaza-Hernandez, V. Florida and Puerto Rico secondary science teachers' knowledge and teaching of climate change science. Int. J. Sci. Math. Educ. 2017, 15, 451-471. [CrossRef]

17. Álvarez-García, O.; Sureda-Negre, J.; Comas-Forgas, R. Evaluación de las competencias ambientales del profesorado de primaria en formación inicial: Estudio de caso. Ensen. Cienc. 2018, 36, 117-141. [CrossRef]

18. Wals, A.E.; Brody, M.; Dillon, J.; Stevenson, R.B. Convergence between science and environmental education. Science 2014, 344, 583-584. [CrossRef] [PubMed]

19. Varela-Losada, M.; Vega-Marcote, P.; Pérez-Rodríguez, U.; Álvarez-Lires, M. Going to action? A literature review on educational proposals in formal Environmental Education. Environ. Educ. Res. 2016, 22, 390-421. [CrossRef]

20. Jensen, B.B.; Schnack, K. The Action Competence Approach in Environmental Education. Environ. Educ. Res. 1997, 3, 163-178. [CrossRef]

21. Varela-Losada, M.; Arias-Correa, A.; Vega-Marcote, P. Evaluación de una propuesta de aprendizaje experiencial para formar al profesorado en Educación Ambiental orientada hacia la Sostenibilidad. Rev. Port. Educ. 2019, in press.

22. Sakschewski, M.; Eggert, S.; Schneider, S.; Bögeholz, S. Students Socioscientific Reasoning and Decision-making on Energy-related Issues-Development of a measurement instrument. Int. J. Sci. Educ. 2014, 36, 2291-2313. [CrossRef]

23. Klein, N. This Changes Everything: Capitalism vs. the Climate; Allen Lane: London, UK, 2014; ISBN 978-1-846-14506-3.

24. Tilbury, D. Education for Sustainable Development. An Expert Review of Processes and Learning. Available online: http://unesdoc.unesco.org/images/0019/001914/191442e.pdf (accessed on 2 April 2019).

25. Vega-Marcote, P.; Varela-Losada, M.; Álvarez-Suárez, P. Evaluation of an educational model based on the development of sustainable competencies in basic teacher training in Spain. Sustainability 2015, 7, 2603-2622. [CrossRef]

26. Varela-Losada, M.; Arias-Correa, A.; Vega-Marcote, P. Training Teachers Committed to Climate Change Mitigation. In Climate Literacy and Innovations in Climate Change Education; Azeiteiro, U.M., Leal Filho, W., Aires, L., Eds.; Springer: Cham, Switzerland, 2018; pp. 307-321. ISBN 978-3-319-70199-8. [CrossRef]

27. Mogensen, F.; Mayer, M. Eco-Schools: Trends and Divergences. A Comparative Study on ECO-School Development Processes in 13 Countries; Austrian Federal Ministry of Education, Science and Culture: Viena, Austria, 2005; ISBN 3-85031-062-0.

28. Wals, A.E. Social Learning towards a Sustainable World; Wageningen Academic: Wageningen, The Netherlands, 2007; ISBN 978-90-8686-031-9.

29. Kyburz-Graber, R. Socioecological Approaches to Environmental Education and Research: A Paradigmatic Response to Behavioral Change Orientations. In International Handbook of Research on Environmental Education; Stevenson, R.B., Brody, M., Dillon, J., Wals, A.E.J., Eds.; Routledge: New York, NY, USA, 2013; ISBN 978-0-415-89238-4.

30. Gifford, R. Environmental Psychology: Principles and Practice, 5th ed.; Optimal Books: Colville, WA, USA, 2014; ISBN 978-0-968-85430-3.

31. Stern, M.J.; Powell, R.B.; Hill, D. Environmental Education Program Evaluation in the New Millennium: What Do We Measure and What Have We Learned? Environ. Educ. Res. 2014, 20, 581-611. [CrossRef]

32. Lave, J.; Wenger, E. Situated Learning: Legitimate Peripheral Participation; Cambridge University Press: Cambridge, UK, 1991; ISBN 978-0-521-42374-8.

33. Vosniadou, S. How Children Learn; International Academy of Education: Brussels, Belgium, 2001.

34. Grande de Prado, M.; Abella García, V. Los juegos de rol en el aula. Teor. Educ. Educ. Cult. Soc. Inf. 2010, 11, $56-84$. 
35. Zeidler, D.L.; Applebaum, S.M.; Sadler, T.D. Enacting a socioscientific issues classroom: Transformative transformations. In Socio-Scientific Issues in Science Classrooms: Teaching, Learning and Research; Sadler, T.D., Ed.; Springer: Dordretch, The Netherlands, 2011; pp. 277-306.

36. OECD. Trends Shaping Education 2013; OECD: Paris, France, 2013. [CrossRef]

37. Öhman, J.; Öhman, M. Participatory approach in practice: An analysis of student discussions about climate change. Environ. Educ. Res. 2013, 19, 324-341. [CrossRef]

38. Kolstad, C.; Urama, K.; Broome, J.; Bruvoll, A.; Cariño Olvera, M.; Fullerton, D.; Gollier, C.; Hanemann, W.M.; Hassan, R.; Jotzo, F.; et al. Climate Change 2014: Mitigation of Climate Change. Contribution of Working Group III to the Fifth Assessment Report of the Intergovernmental Panel on Climate Change; Cambridge University Press: Cambridge, UK, 2014; ISBN 978-1-107-65481-5.

39. Leal Filho, W.; Morgan, E.A.; Godoy, E.S.; Azeiteiro, U.M.; Bacelar-Nicolau, P.; Ávila, L.V.; Mac-Lean, C.; Hugé, J. Implementing climate change research at universities: Barriers, potential and actions. J. Clean. Prod. 2018, 170, 269-277. [CrossRef]

40. Zeidler, D.L. The central role of fallacious thinking in science education. Sci. Educ. 1997, 81, 483-496. [CrossRef]

41. Kolstø, S.D.; Bungum, B.; Arnesen, E.; Isnes, A.; Kristensen, T.; Mathiassen, K.; Mestad, I.; Quale, A.; Tonning, V.; Ulvik, M. Science students' critical examination of scientific information related to socioscientific issues. Sci. Educ. 2006, 90, 632-655. [CrossRef]

42. Stevenson, R.; Stirling, C. Environmental learning agency in diverse cultural contexts. In Engaging Environmental Education: Learning, Culture and Agency; Stevenson, R., Dillon, J., Eds.; Sense Publishers: Rotterdam, The Netherlands, 2010; pp. 219-237. ISBN 978-9-460-91159-0.

43. Prieto, A.; Barbarroja, J.; Reyes, E.; Monserrat, J.; Díaz, D.; Villaroel, M.; Álvarez-Mon, M. Un nuevo modelo de aprendizaje basado en problemas, el ABP $4 \times 4$, es eficaz para desarrollar competencias profesionales valiosas en asignaturas con más de 100 alumnos. Aula Abierta 2006, 87, 171-194.

44. Robottom, I.; Hart, P. Research in Environmental Education: Engaging the Debate; Deakin University: Geelong, Victoria, Australia, 1993; ISBN 978-0730016731.

45. Lotz-Sisitka, H.; Fien, J.; Ketlhoilwe, M. An Overview of Environmental Education Curriculum and Learning Research. In International Handbook of Research on Environmental Education; Stevenson, R.B., Brody, M., Dillon, J., Wals, A.E.J., Eds.; Routledge: New York, NY, USA, 2013; ISBN 978-0-415-89238-4.

46. Stake, R.E. Investigación con Estudio de Casos; Morata: Madrid, Spain, 1999; ISBN 978-8-471-12422-7.

47. Creswell, J.W. Research Design: Qualitative, Quantitative, and Mixed Methods Approaches; Sage Publications: Los Angeles, CA, USA; London, UK; New Delhi, India; Singapore; Washington, DC, USA, 2014.

48. Lincoln, Y.S.; Guba, E.G. Naturalistic Inquiry; Sage Publications: Newbury Park, CA, USA, 1985.

49. Kenis, A.; Mathijs, E. Beyond individual behaviour change: The role of power, knowledge and strategy in tackling climate change. Environ. Educ. Res. 2012, 18, 45-65. [CrossRef]

50. Birchall, J. Qualitative inquiry as a method to extract personal narratives: Approach to research into organizational climate change mitigation. Qual. Rep. 2014, 19, 1-18.

51. Erickson, F. Qualitative research methods for science education. In Second International Handbook of Science Education; Fraser, B., Tobin, K., Eds.; Springer: Dordrecht, The Netherlands, 2012; pp. 1451-1469. ISBN 978-1-4020-9041-7.

52. Bardin, L. Análisis de Contenido; Ediciones Akal: Madrid, Spain, 1991; ISBN 978-84-7600-093-9.

53. Dunlap, R.E.; McCright, A.M. Organized climate change denial. In The Oxford Handbook of Climate Change and Society; Dryzek, J.S., Norgaard, R.B., Schlosberg, D., Eds.; Oxford University Press: New York, NY, USA, 2011; pp. 144-160. ISBN 9780199566600. [CrossRef]

54. Herman, B.C. The Influence of global warming science views and sociocultural factors on willingness to mitigate global warming. Sci. Educ. 2015, 99, 1-38. [CrossRef]

55. PNUD. Human Development Report 2014. Available online: http://hdr.undp.org/sites/default/files/hdr14report-en-1.pdf (accessed on 2 August 2018).

56. Dickinson, J.E.; Kingham, S.; Copsey, S.; Hougie, D.J.P. Employer travel plans, cycling and gender: Will travel plan measures improve the outlook for cycling to work in the UK? Transp. Res. Part D Transp. Environ. 2003, 8, 53-67. [CrossRef]

57. Gardner, G.T.; Stern, P.C. Environmental Problems and Human Behavior, 2nd ed.; Pearson: Boston, MA, USA, 2002; ISBN 978-0-536-68633-6. 
58. Kreuzer, C.; Weber, S.; Off, M.; Hackenberg, T.; Birk, C. Shedding Light on Realized Sustainable Consumption Behavior and Perceived Barriers of Young Adults for Creating Stimulating Teaching-Learning Situations. Sustainability 2019, 11, 2587. [CrossRef]

59. Chhokar, K.; Dua, S.; Taylor, N.; Boyes, E.; Stanisstreet, M. Indian secondary students' views about global warming: Beliefs about the usefulness of actions and willingness to act. Int. J. Sci. Math. Educ. 2011, 9, 1167-1188. [CrossRef]

60. Kollmus, A.; Agyeman, J. Mind the gap: Why do people act environmentally and what are the barriers to pro-environmental behaviour? Environ. Educ. Res. 2002, 8, 239-260. [CrossRef]

61. Schindel-Dimick, A. Supporting youth to develop environmental citizenship within/against a neoliberal context. Environ. Educ. Res. 2015, 21, 390-402. [CrossRef]

62. Vilches, A.; Pérez, D.G. La educación para la sostenibilidad en la Universidad: El reto de la formación del profesorado. Profr. Rev. Curríc. Form. Profr. 2012, 16, 25-43.

63. Farinha, C.; Caeiro, S.; Azeiteiro, U. Sustainability Strategies in Portuguese Higher Education Institutions: Commitments and Practices from Internal Insights. Sustainability 2019, 11, 3227. [CrossRef]

(C) 2019 by the authors. Licensee MDPI, Basel, Switzerland. This article is an open access article distributed under the terms and conditions of the Creative Commons Attribution (CC BY) license (http://creativecommons.org/licenses/by/4.0/). 